\title{
Words Denoting Faba Bean (Vicia faba) in European Languages
}

\begin{abstract}
Aleksandar Mikić
received / primljeno: 18.11.2010. accepted / prihvaćeno: 23.12.2010.

(C) 2011 IFVC

Summary: Faba bean (Vicia faba L.) took part in the 'agricultural revolution' of post-glacial Europe along with other grain legumes and cereals. In order to assess the diversity and the origin of the words denoting faba bean in the languages of Europe, a lexicological study was carried out with emphasis upon etymological dictionaries. The words in almost all modern Indo-European languages in Europe owe their origin to the Proto-Indo-European root *bhabh-, bhabhā, also denoting faba bean. The ProtoAltaic root *bŭkrV, denoting pea, nut and cone, through the Proto-Turkic *burčak, denoting both pea and bean, is responsible for the words in several modern Altaic languages of Europe, while the others are borrowings from Arabic. The origin of the words in modern Caucasian languages is the Proto-Caucasian root * howt $[\bar{a}]$, meaning both bean and lentil. The words in Uralic languages are either borrowings, mostly from Slavic, or derived from their own words denoting pea.
\end{abstract}

Key words: crop history, etymology, Europe, faba bean, lexicology, Vicia faba

\section{Introduction}

Faba bean (Vicia faba L.) originated in the Central Asian centre of diversity (Zeven \& Zhukovsky 1975), unlike many other botanically related grain legume species such as pea (Pisum sativum L.), vetches (Vicia spp.) and vetchlings (Lathyrus spp.) which came mostly from the Near East and Mediterranean. Another peculiarity of faba bean in comparison to its close legume relatives is a lack of evidence about its noncultivated forms and a potential progenitor, being usually considered completely extinct (Tanno \& Willcox 2006). It is, however, one of the first domesticated crops, together with several other legumes, namely pea, bitter vetch (V. ervilia (L.) Willd.), lentil (Lens culinaris Medik.) and chickpea (Cicer arietinum L.), and cereals, with the earliest well preserved archaeobotanical finds 10 millennia old and located in Syria (Zohary \& Hopf 2000). Together with these crops, faba bean took part in the 'agricultural revolution' of post-glacial Europe and quickly spread from Asia Minor, over the Balkans climbing up the flow of Danube, and reached all over the central, western

\footnotetext{
A. Mikić $(\bowtie)$

Institute of Field and Vegetable Crops, Maksima Gorkog 30, 21000 Novi Sad, Serbia

e-mail: aleksandar.mikic@ifvcns.ns.ac.rs
}

and northern parts of the continent already in 6th millennium BC (Rottoli \& Castiglioni 2009). It was simultaneously widespread towards and across the Caucasus to the easternmost borders of Europe and also to other regions of Asia and North Africa. From this time until today, faba bean has become one of the economically most important grain legumes in Europe and the world, used for human consumption, animal feeding and various non-food purposes (Mihailović et al. 2010).

Those bringing what we call today agriculture to Europe met with those who had already lived there and who came there from other directions: some peoples were assimilated by the others, some have survived until the modern day and many merged together and brought forward something new. All these processes resulted in a great ethnic and linguistic diversity but strongly correlated (Cavalli-Sforza \& Seielstad 2001), making Europe a common home to at least three hundred extinct and living languages of six great families (Price 1998). The richest family is IndoEuropean, regarded as stemming from a single ancestral language, Proto-Indo-European, fully developed during the 5th and 4th millennia in the Pontic-Caspian steppe (Anthony 2007) and later divided into present Albanian, Armenian, Baltic, Celtic, Germanic, Hellenic, Indo-Iranian, Italic and Slavic branches. The great and still 
disputed Altaic family is represented in Europe mostly by its Turkic languages. The Basque language, usually considered a language isolate, might be related to the Caucasian languages, making their speakers the descendants of the Paleolithic inhabitants of Europe who retreated before the newcomers to the Pyrenees and the North Caucasus and including both groups into a supposed Dené-Caucasian language superfamily (Ruhlen 2001). The south-east regions of the Caucasus are home to Georgian and three more Kartvelian languages. The Uralic language family in Europe is represented by their rich Finno-Ugric branch, of which Finnish and Hungarian are most known and spoken, while the Maltese language is the only Afro-Asiatic language spoken in Europe.

The ( $\mathrm{r}$ )evolution of agriculture in Europe, as we find, went in parallel with the development of its languages. In some cases, peoples welcomed faba bean and other primeval crops with the newcomers who had brought them from their original homeland, and they imported the crops together with their names. In other cases, those who had migrated found the familiar crops already present in their new homes and started to use the words the aboriginal population had been using. In some cases, the original words happened to be forgotten and were replaced with those from neighbouring languages, especially if new cropping systems were introduced. Although all this makes a rather complex background, this research was aimed at assessing the diversity and the origin of the words denoting faba bean in the languages of Europe.

\section{Materials and Methods}

In order to complete the goals of this preliminary lexicological essay, the analysis of the origin and diversity of the words denoting faba bean in European languages has been carried out in two major steps.

The first action targeted the past and the present diversity and comprised searching available printed and online dictionaries of the most important living and extinct European languages and collecting all the words, together with their modifications, that denote faba bean.

The second task was to examine the existing etymological dictionaries and other relevant historical linguistics resources, related to a single language and a whole language family, in order to collect all the root words related to faba bean in the ancestors of modern European languages and thus shed light on the question of the origin.
Finally, I have tried to bring these two steps together in an integrated analysis that could provide both linguists and crop historians with attested and assumed forms of the words denoting faba bean in living and extinct European languages, in order to try to explain how they developed, diversified, disappeared and survived. This should also initiate further interdisciplinary approaches to this complex and interesting issue, proving that natural and social sciences may assist each other to better understand the past of mankind.

\section{Results and Discussion}

\section{Indo-European languages}

The collected words related to faba bean in the modern Indo-European languages and their major dialects show a high degree of mutual similarity, especially between and within the most abundant branches such as Germanic, Italic and Slavic (Tab. 1).

It is considered that the Proto-Indo-European root denoting faba bean was *bhabh-, bhabbä, meaning literally something swelling. Its evolution followed the migrations of the Indo-European tribes and brought forth numerous derivations (Pokorny 1959, Nikolaev 2007):

- The supposed Proto-Albanian root *bhakä gave the form in Modern Albanian;

- The extinct Old Prussian language preserved the primeval Proto-Indo-European root to a greater extent, with baba and babo, than its surviving relatives such as Latvian and Lithuanian;

- The Proto-Germanic language root *bau$n \bar{o}(n-)$, with a presumed more ancient form of $* b a b-n-\bar{o}$, is responsible for the words denoting faba bean in all modern Germanic languages, as witnessed by the extinct and mediating bone in Middle Dutch, bèan in Old English, bāne in Old Frisian, bōna in both Old High German and Old Low German and baun in Old Norse, with the last one passing it along with its meaning to all modern Goidelic Celtic languages, namely Irish, Manx and Scottish Gaelic (Macbain 1911);

- In the Hellenic languages, there was a shift of meaning from faba bean to lentil, making yaxós denoting the latter in both Old and Modern Greek, while some connect it to the Greek verb

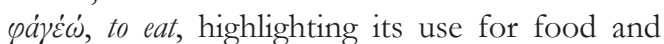
feed by the ancient Greeks and Romans (Duc et al. 2010);

- In the Italic languages, there are haba in extinct Faliscan and faba in Latin, with the latter 
Table 1. The words denoting faba bean in modern Indo-European languages and dialects of Europe Tabela 1. Reči koje označavaju bob u savremenim indoevropskim jezicima i dijalektima Evrope

\begin{tabular}{|c|c|c|c|c|c|}
\hline $\begin{array}{l}\text { Branch } \\
\text { Grana }\end{array}$ & $\begin{array}{l}\text { Language } \\
\text { Jezik }\end{array}$ & $\begin{array}{l}\text { Word } \\
\text { Reč }\end{array}$ & $\begin{array}{l}\text { Branch } \\
\text { Grana }\end{array}$ & $\begin{array}{l}\text { Language } \\
\text { Jezik }\end{array}$ & $\begin{array}{l}\text { Word } \\
\text { Reč }\end{array}$ \\
\hline \multicolumn{2}{|l|}{ Albanian } & bathë & \multirow{12}{*}{ Italic } & Friulian & fave \\
\hline \multicolumn{2}{|l|}{ Armenian } & lobi & & Galician & faba \\
\hline \multirow{2}{*}{ Baltic } & Latvian & pupas & & Italian & fava \\
\hline & Lithuanian & рира & & Judaeo-Spanish & ava \\
\hline \multirow{6}{*}{ Celtic } & Breton & fav & & Ligurian & bazann-a \\
\hline & Cornish & fav & & Occitan & fava \\
\hline & Irish & pónaire & & Picard & fefe \\
\hline & Manx & poanrey & & Portuguese & fava \\
\hline & Scottish Gaelic & pònair & & Romanian & bob \\
\hline & Welsh & $f f a$ & & Sardinian & $f a$ \\
\hline \multirow{10}{*}{ Germanic } & Danish & bonne & & Spanish & baba \\
\hline & Dutch & boon & & Walloon & féve \\
\hline & English & bean & \multirow{15}{*}{ Slavic } & Belarusian & bob \\
\hline & Faroese & bona & & Bulgarian & bob \\
\hline & Frisian & beanne & & Croatian & bob \\
\hline & German & Bohne & & Czech & bob \\
\hline & Icelandic & baun & & Kashubian & bób \\
\hline & Norwegian & bonne & & Lower Sorbian & bob \\
\hline & Swedish & böna & & Macedonian & bob \\
\hline & Yiddish & bob & & Polish & bób \\
\hline Hellenic & Greek & konkiá & & Russian & bob \\
\hline \multirow{2}{*}{ Indo-Iranian } & Ossetic & qadur & & Rusyn & bob \\
\hline & Romany & boba & & Serbian & $b o b$ \\
\hline \multirow{4}{*}{ Italic } & Aragonese & $f a b a$ & & Slovak & bob \\
\hline & Catalan & fava & & Slovenian & bob \\
\hline & Corsican & fava & & Ukrainian & bib \\
\hline & French & feve; feverole & & Upper Sorbian & bob \\
\hline
\end{tabular}

being ultimate source of the words denoting faba bean in all modern Italic languages derived from Vulgar Latin, and commonly known as Romance languages. From this Latin it was borrowed by Brythonic, the language which gave the Brythonic Celtic languages, namely Breton, Cornish and Welsh;
- The Proto-Slavic root denoting faba bean, ${ }^{*} b o b \breve{u}$, proved to be also conservative, retaining almost the unchanged form in all its living descendants (Vasmer 1953, Skok 1971). It was imported by Romanian, as bob, and Romani, as boba.

The Armenian word denoting faba bean might be a borrowing of lobó-s, the Old Greek word

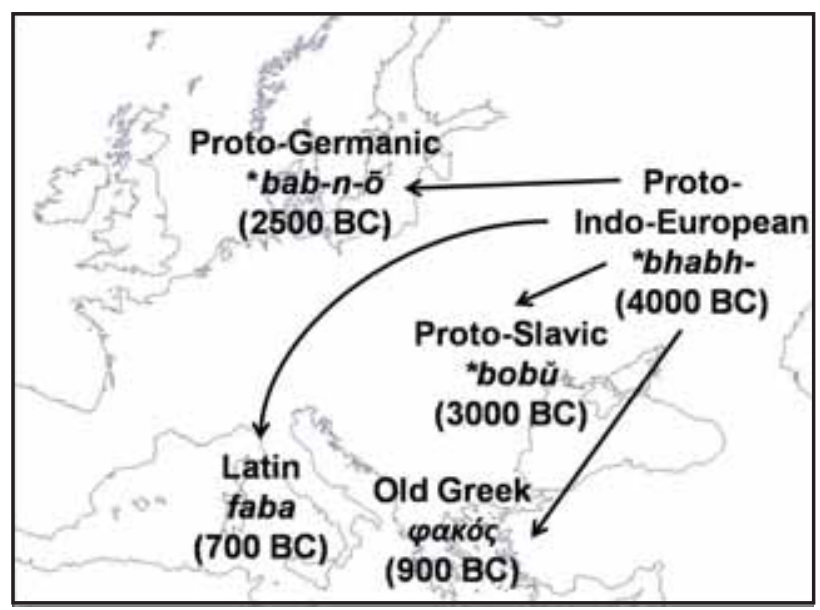

Fig. 1. A simplified geographic and historical evolution of the Proto-Indo-European word denoting faba bean into its direct descending languages

Slika 1. Pojednostavljena geografska i istorijska evolucija praindoevropske reči koja označava bob u njenim neposrednim jezicima naslednicima 
denoting a pod of leguminous plants that, in its turn, was derived from the Proto-Indo-European *leb-, denoting blade (Nikolaev 2007).

\section{Altaic languages}

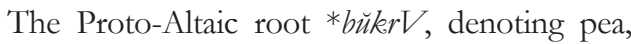
nut and cone (Starostin et al. 2003), through the Proto-Turkic * burřk k, denoting both pea and bean, is responsible for the words denoting faba bean in several modern Altaic languages of Europe, such as Bashkir, Chuvash, Crimean Tatar, Karaim, Kazakh, Kumyk and Tatar (Tab. 2), where in most cases and with an adjective, it literally means blacke pea, probably because of the black colour of mature faba bean pods. The fact that the Proto-Turkic word denoted both pea and bean may mean that it simply denoted a pulse, that is, something that was cooked and eaten in such way, while they differed from each other only in seed size and shape, with pea smaller and more round and bean larger and more irregularly shaped.

The Arabic word denoting faba bean, bakl, was imported in some Altaic languages, most notably Turkish (Nişanyan 2002) and Karaim.

Due to the geographic proximity, the Azeri word denoting faba bean could have the same origin as the one in Armenian language, while the Kalmyk word denoting faba bean is obviously a borrowing from Russian.

\section{Caucasian languages}

The Proto-Caucasian root *howt $[\bar{a}\rceil$, meaning both bean and lentil (Nikolayev \& Starostin 1994), is responsible for the words denoting faba bean in some modern Caucasian languages such as Aknadian, Avar and Tindi (Tab. 3). This root is considered to be related to the Proto-Basque *ithar, denoting pea, faba bean, vetch and heather and giving the Modern Basque ilar, denoting only pea (Bengtson 2007), and thus another proof of the theory on the Dené-
Caucasian language superfamily.

Another Proto-Caucasian root, *qŏr'a', denoting solely pea (Nikolaev \& Starostin, 1994), gave rise to the words denoting faba bean in some other modern Caucasian languages such as Archi, Chechen, Ingush, Lak, Lezgian, Tabassaran and Adyghe, with very little difference in comparison to the words denoting pea (Mikić 2009).

The alternative Lezgian word denoting faba bean, paxla, is a borrowing from the Turkish language.

\section{Uralic languages}

The majority of the words denoting faba bean in the modern Uralic languages of Europe are borrowings. The speakers of the westernmost ones such as Estonian, Finnish, Ingrian, Livonian, Sami and Võro (Tab. 4) imported both the faba bean crop and the word denoting it from their Slavic neighbours (Stoddard 2009). The same is true for Hungarian, which borrowed its word denoting faba bean from the South Slavs who welcomed Hungarian tribes in the Carpathian Basin in 9th century AD (Skok 1971). Some, like Mari, obviously borrowed their words denoting faba bean from their Turkic neighbours.

There are some indications that the ProtoUralic root kača, denoting hole and cavity (Starostin 2005), could have given origin to the words denoting pea and faba bean in some of the contemporary Uralic languages, closest to their original homeland, such as Erzya, Moksha and Udmurt (Lytkin \& Gulyaev 1970).

\section{Other language families of Europe}

Similarly to Armenian and Azeri, the words denoting faba bean in modern Kartvelian languages, such as the Georgian lobio, may be borrowings of the Old Greek lobó-s.

Table 2. The words denoting faba bean in modern Altaic languages of Europe

Tabela 2. Reči koje označavaju bob u savremenim altajskim jezicima Evrope

\begin{tabular}{|c|c|c|}
\hline $\begin{array}{l}\text { Branch } \\
\text { Grana }\end{array}$ & $\begin{array}{l}\text { Language } \\
\text { Jezik }\end{array}$ & $\begin{array}{l}\text { Word } \\
\text { Reč }\end{array}$ \\
\hline Mongolian & Kalmyk & bob \\
\hline \multirow{10}{*}{ Turkic } & Azeri & lobya \\
\hline & Bashkir & baqsa borsağa \\
\hline & Chuvash & nímës parsí \\
\hline & Crimean Tatar & pasle \\
\hline & Karachay-Balkar & bans qudoru \\
\hline & Karaim & baqla; burcacyk; bob \\
\hline & Kazakh & iri bursaq \\
\hline & Kumyk & burcaq \\
\hline & Tatar & bakca borcagl \\
\hline & Turkish & bakla \\
\hline
\end{tabular}


Table 3. The words denoting faba bean in modern Caucasian languages

Tabela 3. Reči koje označavaju bob u savremenim kavkaskim jezicima

\begin{tabular}{|l|l|c|}
\hline $\begin{array}{l}\text { Branch } \\
\text { Grana }\end{array}$ & $\begin{array}{l}\text { Language } \\
\text { Jezik }\end{array}$ & \multicolumn{1}{c|}{ Word } \\
Reč
\end{tabular}

Table 4. The words denoting faba bean in modern Uralic languages of Europe Tabela 4. Reči koje označavaju bob u savremenim uralskim jezicima Evrope

\begin{tabular}{|l|l|c|}
\hline $\begin{array}{l}\text { Branch } \\
\text { Grana }\end{array}$ & $\begin{array}{l}\text { Language } \\
\text { Jezik }\end{array}$ & \multicolumn{1}{|c|}{ Word } \\
Reč
\end{tabular}

The Maltese word denoting faba bean, fula, is a modification of the Arabic fül-, originating directly from the Proto-Semitic *pül-, denoting beans, and ultimately from the Proto-Afroasiatic *pal-, denoting both bean and corn in general (Militarev 2006).

The word denoting faba bean in modern Basque, $b a b a$, is a borrowing from the Latin language (Trask 2008).

\section{Conclusions}

Although preliminary and highly incomplete, the gathered and presented lexicological evidence may provide both the linguistic and the life sciences' audience with a valuable testimony to the role faba bean and other traditional grain legumes had in everyday life of the Europe nations. Some of the collected words, especially those of the IndoEuropean language family, prove to be highly conservative and thus preserve their most ancestral forms in almost unchanged forms. Others witness a rich and continuous exchange of both crops and words denoting them among the European peoples that brought forth modern nations. This research may hopefully contribute to the interdisciplinary approach by agricultural sciences, archaeobotany and linguistics to the ever puzzling issue of the very origins of European civilization.

Future research on the legume lexicology should surely aim not only to determining the origins and the evolution of the words denoting individual species, but also to give clues of their mutual horizontal transfer where faba bean played a very important role. In many languages, such as Germanic, the words such as the English bean became much more associated to Phaseolus beans than to $V$. faba. At the same time, bean became a kind of root word for numerous bean-like seeds or products, such as coffee bean, adzuki bean or soybean. Among the next steps on the faba bean lexicology will surely be its agronomical aspects which deserve a study of their own that would deal with a rather rare multitude of its names denoting various types, depending on seed size or growing conditions, such as broad bean or horse bean in English, feve des marais in French or Ackerbohne in German, as recognised already by Pliny.

Regardless of the extent it is used at this very moment or its form, what the scientists recently labelled as faba bean and what is globally known as Vicia faba remains an important part of our everyday life, our diets, our speech and our culture. 
Inwitári! Mistress of Bean!

No mortal eye has ever seen

Thy rosy cheeks as bean in bloom

To love thee's my eternal doom.

\section{References}

Anthony D W (2007): The Horse, the Wheel, and Language: How Bronze-Age Riders from the Eurasian Steppes Shaped the Modern World. Princeton University Press, New Jersey

Bengtson J (2007): Basque etymology [Online]. Available at http://starling.rinet.ru (Cited 18 November 2010, verified 18 November 2010). The Tower of Babel, an International Etymological Database Project

Cavalli-Sforza L L, Seielstad M (2001): Genes, Peoples and Languages. Penguin Press, London

Duc G, Bao S, Baum M, Redden B, Sadiki M, Suso M J, Vishniakova M, Zong X (2010): Diversity maintenance and use of Vicia faba L. genetic resources. Field Crop. Res. 115: 270278

Lytkin V I, Gulyaev E S (1970) Kratkii etimologicheskii slovar' komi yazyka. Nauka, Moscow

Macbain A (1911): Etymological Dictionary of the Gaelic Language. Eneas Mackay, Inverness

Mihailović V, Mikić A, Vasić M, Ćupina B, Đurić B, Duc G, Stoddard F L, Hauptvogel P (2010): Neglected legume crops of Serbia - Faba bean (Vicia faba). Ratar. Povrt. / Field Veg. Crop. Res. 47: 27-32

Mikić A (2009): Words denoting pea (Pisum sativum) in European languages. Pisum Genet. 41: 29-33

Militarev A. (2006): Semitic etymology [Online]. Available at http://starling.rinet.ru (Cited 18 November 2010, verified 18 November 2010). The Tower of Babel, an International Etymological Database Project

Nikolayev S L (2007): Indo-European etymology [Online]. Available at http://starling.rinet.ru (Cited 18 November 2010, verified 18 November 2010). The Tower of Babel, an International Etymological Database Project

Nikolaev S L, Starostin S A (1994): A North Caucasian Etymo- logical Dictionary. Asterisk, Moscow

Nişanyan S (2002): Sözlerin Soyağaci: Çağdaş Türkçenin Etimolojik Sözlüğü. Adam yay., Istanbul

Pokorny J (1959): Indogermanisches Etymologisches Wörterbuch, 1. Francke, Bern

Price G (1998): An Encyclopedia of the Languages of Europe. Blackwell, Oxford

Rottoli M, Castiglioni E (2009): Prehistory of plant growing and collecting in northern Italy, based on seed remains from the early Neolithic to the Chalcolithic (c. 5600-2100 cal B.C.). Veget. Hist. Archaeobot. 18: 91-103

Ruhlen M (2001): Il Dene-caucasico: una nuova famiglia linguistica. Pluriverso 2: 76-85

Skok P (1971): Etimologijski rječnik hrvatskoga ili srpskoga jezika, 1 (A - J). Jugoslavenska akademija znanosti i umjetnosti, Zagreb

Starostin S, Dybo A, Mudrak O (2003): Etymological Dictionary of the Altaic Languages. Brill, Leiden

Starostin S (2005): Uralic etymology [Online]. Available at http://starling.rinet.ru (Cited 18 November 2010, verified 18 November 2010). The Tower of Babel, an International Etymological Database Project

Stoddard F L, Hovinen S, Kontturi M, Lindström K, Nykänen A (2009): Legumes in Finnish agriculture: history, present status and future prospects. Agric. Food Sci. 18: 191-205

Tanno K, Willcox G (2006): The origins of cultivation of Cicer arietinum L. and Vicia faba L.: early finds from Tell el-Kerkh, north-west Syria, late 10th millennium B.P. Veget. Hist. Archaeobot. 15: 197-204

Trask R L (2008): Etymological Dictionary of Basque. University of Sussex, Brighton

Vasmer M (1953): Russisches etymologisches Wörterbuch, 1 (A-K). Carl Winters Universitätsverlag, Heidelberg

Zeven A C, Zhukovsky P M (1975): Dictionary of Cultivated Plants and Their Centres of Diversity. Centre for Agricultural Publishing and Documentation, Wageningen

Zohary D, Hopf M (2000): Domestication of Plants in the Old World: the Origin and Spread of Cultivated Plants in West Asia, Europe and the Nile Valley. Oxford University Press, Oxford

\title{
Reči koje označavaju bob (Vicia faba) u evropskim jezicima
}

\author{
Aleksandar Mikić \\ Institut za ratarstvo i povrtarstvo, Maksima Gorkog 30, 21000 Novi Sad, Srbija
}

Izvod: Bob (Vicia faba L.) je uzeo učešća u tzv. poljoprivrednoj revoluciji Evrope nakon poslednjeg ledenog doba zajedno sa ostalim zrnenim mahunarkama i strninama. U cilju utvrđivanja raznolikosti i porekla reči koje označavaju bob u evropskim jezicima, izvršeno je leksikološko istraživanje sa naglaskom na etimološkim rečnicima. Reči u skoro svim savremenim indoevropskim jezicima Evrope vode poreklo od praindoevropskog korena *bhabh-, bhabhä, koji takođe označava bob. Praaltajski koren *bǔkrV, koji označava grašak, orah i šišarku, kroz pratursko *buř̌ak, koje označava grašak i bob, dao je reči u nekim savremenim altajskim jezicima Evrope, dok se u ostalim radi o pozajmicama iz arapskog. Poreklo reči u savremenim kavkaskim jezicima nalazi se u prakavkaskom korenu *bowt [ā], značenja bob i sočivo. Reči u uralskim jezicima su pozajmice, uglavnom iz slovenskih jezika, ili izvedene iz izvornih uralskih reči koje označavaju grašak.

Ključne reči: bob, etimologija, Evropa, istorija gajenih biljaka, leksikologija, Vicia faba 